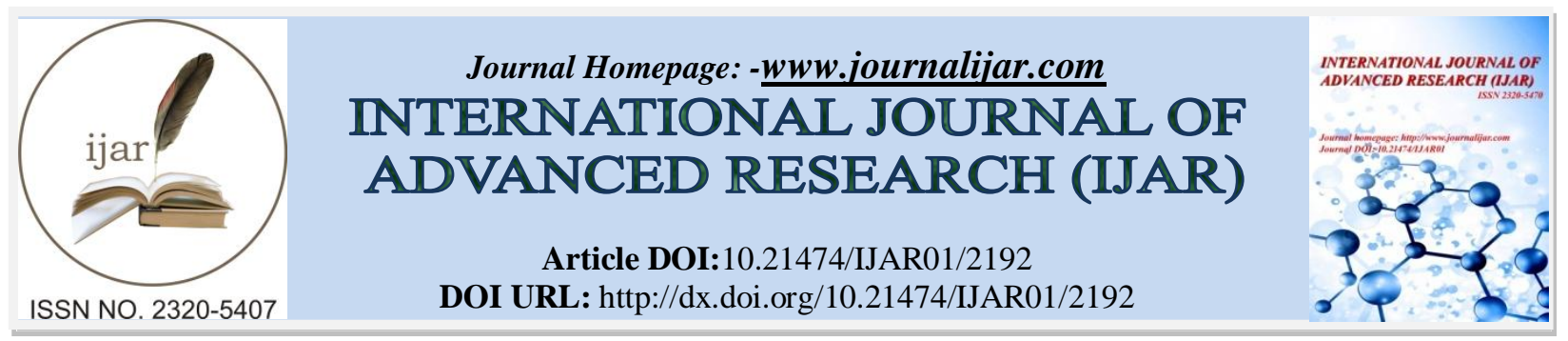

RESEARCH ARTICLE

\title{
EFFECT OF 5 ANIMAL MANURES (PIG, POULTRY, RABBIT, CATTLE, AND SHEEP) ON NUTRITIONAL QUALITY OF EARTHWORM MEAL (EISENIAFETIDA) IN VERMICOMPOST.
}

\section{Vodounnou D. S. Juste Vital ${ }^{{ }^{*}}$, Kpogue Diane N. S. ${ }^{2}$, DjissouArnauldM.S ${ }^{1}$,Mensah Guy Apollinaire ${ }^{3}$ and Fiogbe Emile Didier ${ }^{1}$.}

1. Laboratory of Research on Wetland, Department of Zoology, Faculty of Sciences \& Techniques, University of Abomey-Calavi, 01 BP 526 Cotonou Benin.

2. Agriculture University of Ketou/ EAqBP 43 Ketou Benin.

3. National Institute of Agriculture Research of the Benin 01 BP 884 Cotonou Benin.

\section{Manuscript Info}

Manuscript History

Received: 27 September 2016

Final Accepted: 30 October 2016

Published: November 2016

Key words:-

Effect, animal manures, earthworm meal, nutritional quality

\section{Abstract}

Earthworms were cultured with five animal manures firstly, harvested and dried. The aim of the study was to evaluate the effect of pig, poultry, rabbit, cattle, and sheep manures on the nutritional quality of earthworm meal. The Growth parameters of earthworm production and biochemical parameters of earthworm meal were determined. At the end of the study, the growth parameters of earthworm production and the biochemical parameters of earthworm meal varied with the different used substrates $(\mathrm{P}<0.05$ ). The produce (worm g/ $\mathrm{Kg}$ substrate) were: $41.33 \pm 3.27$ for cattle manure $>36.11 \pm 2.70$ obtained in pig manure $>22.11 \pm 4.73$ recorded in rabbit manure $>10.55 \pm 2.28$ observed in poultry manure $>2.66 \pm 1.61$ for sheep manure. The highest protein rate $(51.38 \pm 0.05 \%)$ in earthworm meal was obtained in pig manure and the lowest $(42.45 \pm 0.08 \%)$ sheep manure. The earthworm production and the biochemical quality of earthworm meal are greatly affected by the earthworm feeding substrates.

Copy Right, IJAR, 2016,. All rights reserved.

\section{Introduction:-}

The quality of the nutritional ingredient is essential for animal growth performance. Animal protein in animal feeds and in human food is essential for growth and health (Bhorgin and Uma, 2013). Earthworms are terrestrial invertebrates with thousands of species grouped into three categories according to their behavior in the natural environment (Vodounnouet al., 2015). It meal is as good as fish meal in terms of quality and has been found to be an efficient substitute for fish meal in domestic animal diets (Bhorgin and Uma, 2013). The potential nutrient value of earthworm has been studied by several authors. Safarkhanloet al. (2009) working on Dendrobaenavenetafound that the worm is a good nutrient element. According to Stafford and Tacon (1984), Dendrodrilussubrubicunduscontains $65 \%$ crude protein. Earthworm meal is rich in amino acids and fat acids Omega3 (Dynes, 2003). The content of lysine in earthworm flour is significant, representing the daily requirement of children between the age of 2 and 5 years (Segovia, 1996). The average earthworms have been shown to contain $60-70 \%$ crude protein and very little crude fibre $(<5 \%)$ which result in a high concentration of highly digestible energy 16-17kJ/g (Sabine, 1983; Lee, 1985). Earthworms contain also significant amount of several minerals that are nutritionally important (Paolettiet al., 2011).

Corresponding Author:-Vodounnou D. S. Juste Vital.

Address:-Laboratory of Research on Wetland, Department of Zoology, Faculty of Sciences \& Techniques, University of Abomey-Calavi, 01 BP 526 Cotonou Benin. 
Moreover, the earthworms are used through the urban, industrial and agricultural organics manure recycling with an aim of obtaining animal protein and vermicompost (Manyuchi and Phiri, 2013; Manyuchiet al., 2014). It is produced by many organic manures such as animal manure. Pig, poultry, rabbit, cattle, and sheep manure can be used to produce earthworm (Vodounnouet al., 2016). The chemical quality of these manures is different and this difference may influence the nutritional quality of ground worms produced with these manures. Earthworms are described as resources with high protein content and protein quality which were shown to differ according to earthworm species and, to a lesser extent, the feed substrate (Taconet al.,1983; Stafford and Tacon, 1984; Sun et al.,1997; Changguoet al.,2006; Sogbesanet al.,2007; Dong et al.,2010; Tuan, 2010). It is proved also that the substrate of earthworm production can affect the earthworm productivity (Vodounnouet al., 2016). The aim of this study is to evaluate the effect of these various animal manures (pig, poultry, rabbit, cattle, and sheep) on the nutritional quality of earthworm meal.

\section{Materials and methods:- Culture of earthworms:-}

Earthworms were cultured in the Laboratory of Research on the Wetlands (LRZH) of the University of AbomeyCalavi.Different animal manures (pig, poultry, rabbit, cattle, and sheep) were collected from animal farms in Abomey-Calavi. The animal manures were used 14 days after the collection, because pre-composting is very essential to avoid the death of the worm (Gunadi and Edwards, 2003). Moisture, ash, total carbon, organic matter, nitrogen and total phosphorus were analyzed in the different substrates before the study (table1). During the study, parameters such as temperature and $\mathrm{pH}$ were measured every week. The study was carried out in triplicate (5 X3) in jar of $12 \mathrm{l}$ content for 3 months. In each jar, $2 \mathrm{~kg}$ of substrate and $30 \mathrm{~g}$ of mature earthworms were sown. Each month, $500 \mathrm{~g}$ of substrate were completed in each jar. The harvesting of earthworm was done after the 3 month production time (Vodounnouet al., 2015).

\section{Growth parameters:-}

Growth parameters: Growth rate and Produce have been calculated

With:-

$$
G R=\frac{f w-i w}{t 2-t 1} P=\frac{f w-i w}{Q}
$$

$\mathbf{I W}=$ Initial weight of the worms, $\mathbf{F W}=$ Final weight of the worms, $\mathbf{t} \mathbf{1}=$ Start time of the experiment (in days), $\mathbf{t} \mathbf{2}=$ End period of the experiment (in days), $\mathbf{Q}=$ Total manure (in $\mathrm{kg}$ ), $\mathbf{P}=$ Produce (g/earthworm/ $\mathrm{kg}$ of $\mathrm{manure}$ ), $\mathbf{G R}=$ Growth rate (g worm/day)

\section{Earthworm nutritional quality:-}

After harvesting, the earthworm were dried and proximate composition of different substrates used to produce earthworm were analyzed for crude protein, Nitrogen, ash and humidity content according to Association of Analytical Chemist methods AOAC (2000).

\section{Statistical analysis:-}

Differences in growth rate, Produce earthworm and proximate composition of earthworm meal in different substrates, were tested by one-factorial ANOVA with StatView software after verifying the homogeneity of variances using "Hartley's test". Significant differences between treatments means $(\mathrm{P}<0.05)$ were determined using Fisher's least- significant difference test (Saville, 1990). Results are given as means \pm standard error.

\section{Results:-}

\section{Proximate composition of the substrates:-}

The moisture in the organic substrate, before its utilization, varied between $6.84 \%$ (poultry) and $12.66 \%$ (rabbit). The ash varied between $31.48 \%$ (pig) and 60.24 (cattle) \% (table 1). The carbons of different organic substrates were in the range of $21.31 \%$ in poultry to $37.34 \%$ in rabbit manure. Phosphorus content ranged from $0.37 \%$ in cattle manure to $1.04 \%$ in rabbit manure. The nitrogen ranged from $2.05 \%$ in pig to $2.56 \%$ in sheep manure. The C:N ratio of different organic substrates were in the range of 11.19 in cattle manure to 19.39 in pig manure. 
Table 1:-Proximate composition of the substrates.

\begin{tabular}{|l|l|l|l|l|l|l|}
\hline $\begin{array}{l}\text { Organicsubstr } \\
\text { ates }\end{array}$ & $\begin{array}{l}\text { Moisture } \\
\text { content \% }\end{array}$ & $\begin{array}{l}\text { Ash } \\
\text { \% }\end{array}$ & $\begin{array}{l}\text { Organicmatter } \\
\text { \% }\end{array}$ & $\begin{array}{l}\text { Phosphorus } \\
\text { (P)\% }\end{array}$ & $\begin{array}{l}\text { Carbon (C ) } \\
\text { \% }\end{array}$ & $\begin{array}{l}\text { Nitrogen (N) } \\
\text { \% }\end{array}$ \\
\hline Rabbit & 12.66 & 35.62 & 64.38 & 1.04 & 37.34 & 2.46 \\
\hline sheep & 11.76 & 39.55 & 60.45 & 0.59 & 35.06 & 2.99 \\
\hline cattle & 8.71 & 60.24 & 39.76 & 0.37 & 23.06 & 2.06 \\
\hline Pig & 10.29 & 31.48 & 68.52 & 0.42 & 39.74 & 2.05 \\
\hline Poultry & 6.84 & 63.27 & 36.73 & 0.6 & 21.31 & 1.82 \\
\hline
\end{tabular}

Growth performance and organic substrate utilization:-

The study started with earthworm production (E. fetida) with five animal manures. Thegrowth performance and organic substrate utilization (final weight and growth rate) after harvesting are observed and treated (table 2). The earthworm growth rate and production were determined according to different animal manures $(\mathrm{P}<0.05)$. Growth rate values ranged between $0.06 \pm 0.06$ (sheep manure) and $1.44 \pm 0.13$ (cattle manure) (table 2).

Table 2:-growth performance, and organic substrate utilization

\begin{tabular}{|l|l|l|l|l|l|}
\hline Parameters & Poultry & Rabbit & Sheep & Cattle & Pig \\
\hline IW $(\mathrm{g})$ & $30.00 \pm 0.00^{\mathrm{a}}$ & $30.00 \pm 0.00^{\mathrm{a}}$ & $30.00 \pm 0.00^{\mathrm{a}}$ & $30.00 \pm 0.00^{\mathrm{a}}$ & $30.00 \pm 0.00^{\mathrm{a}}$ \\
\hline FW $(\mathrm{g})$ & $65.64 \pm 6.76^{\mathrm{a}}$ & $92.33 \pm 14.59^{\mathrm{b}}$ & $36.00 \pm 5.23^{\mathrm{c}}$ & $152.00 \pm 9.72^{\mathrm{d}}$ & $136.33 \pm 7.11^{\mathrm{e}}$ \\
\hline GR $(\mathrm{g}$ worm/day) & $0.39 \pm 0.06^{\mathrm{a}}$ & $0.69 \pm 0.14^{\mathrm{b}}$ & $0.06 \pm 0.06^{\mathrm{c}}$ & $1.44 \pm 0.13^{\mathrm{d}}$ & $1.27 \pm 0.08^{\mathrm{e}}$ \\
\hline
\end{tabular}

Each value is mean \pm SE of triplicates. Means on the same line followed by different superscripts are significantly different $(\mathrm{P}<0.05)$.

The produce (worm g/ Kg substrate) were: $(41.33 \pm 3.27)$ for cattle manure $>(36.11 \pm 2.70)$ for pig manure $>(22.11$ $\pm 4.73)$ for rabbit manure $>(10.55 \pm 2.28)$ for poultry manure $>(2.66 \pm 1.61)$ for sheep manure. The highest produce was observed with cattle manure (Fig 1)

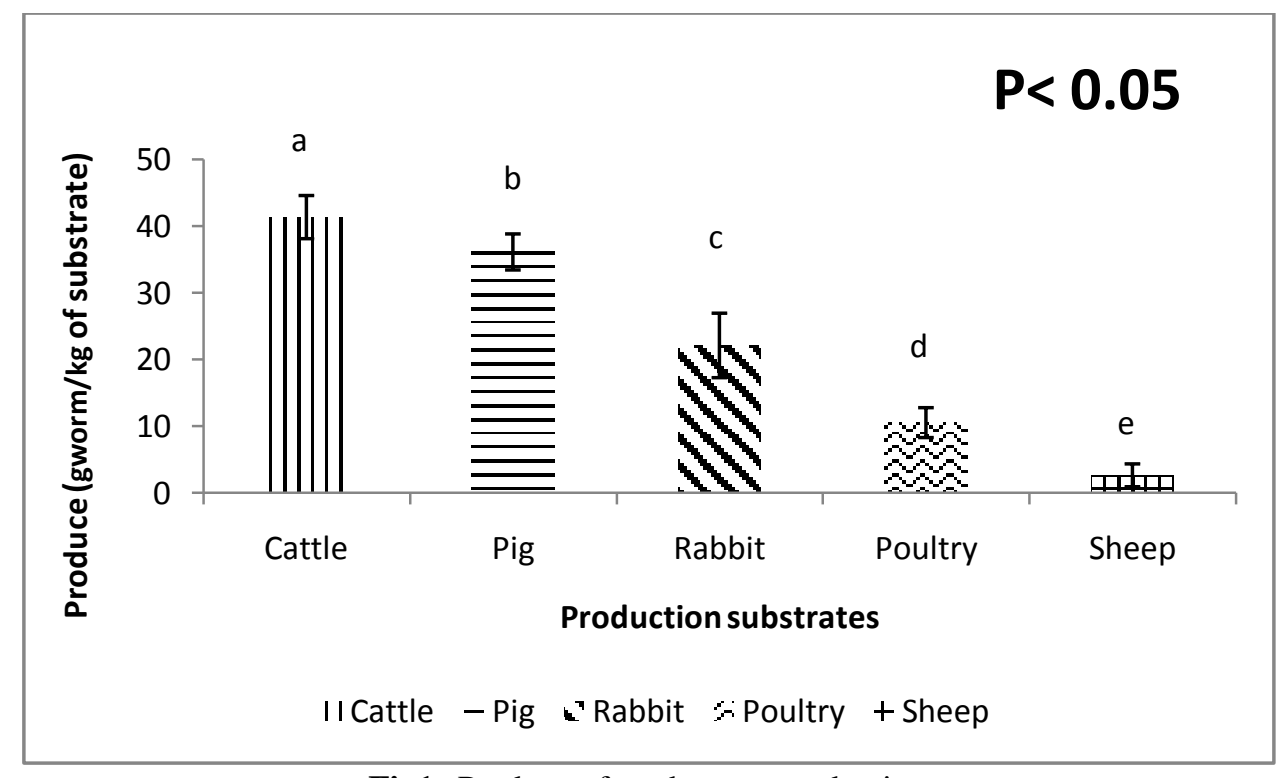

Fig1:-Produce of earthworm production.

Proximate composition of earthworm meal:-

The proximate composition of earthworm meal (humidity, Nitrogen, protein and ash) varied with the different used animal manures $(\mathrm{P}<0.05)$. The nutritional status of earthworm dried powder was shown in Table 3 . At the end of the study, the pig manure earthworm meal has the highest protein contents. Protein values in earthworm meals ranged between $51.38 \pm 0.05 \%$ (pig manure) and $42.45 \pm 0.08 \%$ (sheep manure) (Fig 2) 
Table 3:- Proximate composition of earthworm meal with different substrates

\begin{tabular}{|l|l|l|l|l|l|}
\hline Parameters & cattle & Rabbit & Sheep & pig & Poultry \\
\hline humidity & $86.09 \pm 0.02^{\mathrm{a}}$ & $85.15 \pm 0.5^{\mathrm{b}}$ & $84.40 \pm 0.5^{\mathrm{c}}$ & $86.41 \pm 0.05^{\mathrm{d}}$ & $84.5 \pm 0.05^{\mathrm{c}}$ \\
\hline Ash & $18.38 \pm 0.05^{\mathrm{a}}$ & $14.56 \pm 0.05^{\mathrm{b}}$ & $18.55 \pm 0.05^{\mathrm{c}}$ & $13.51 \pm 0.05^{\mathrm{d}}$ & $20.95 \pm 0.03^{\mathrm{e}}$ \\
\hline Nitrogen & $6.81 \pm 0.08^{\mathrm{a}}$ & $7.28 \pm 0.05^{\mathrm{b}}$ & $6.79 \pm 0.05^{\mathrm{a}}$ & $8.22 \pm 0.05^{\mathrm{c}}$ & $7.37 \pm 0.05^{\mathrm{b}}$ \\
\hline
\end{tabular}

Each value is mean \pm SE of triplicates. Means on the same line followed by different superscripts are significantly different $(\mathrm{P}<0.05)$.

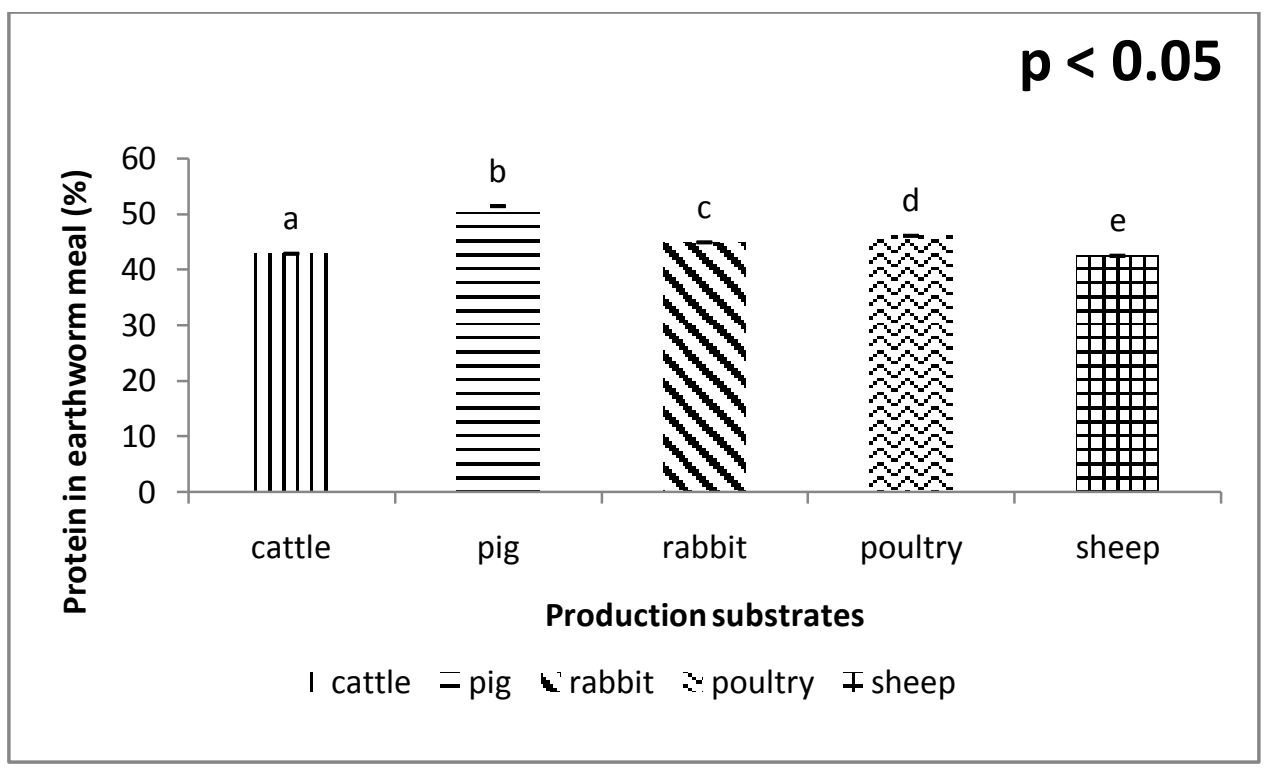

Fig 2:-Protein rate in earthworm meal with different production substrates.

Ash (\%) were: $20.95 \pm 0.03$ for poultry manure $>18.55 \pm 005$ for sheep manure $>18.38 \pm 0.05$ for cattle manure $>14.56 \pm 0.05$ for rabbit manure $>13.51 \pm 0.05$ for pig manure (Table 3 ).

\section{Discussion:-}

\section{Earthworm production:-}

Earthworm production depends on the biochemical quality of the feed substrates (Edwards, 1988). The animal manures used in this study don't have the same biochemical quality. At the end of this production, the growth rate and produce varied in the different used feed substrates $(\mathrm{P}<0.05)$. The growth rate ranged between $0.06 \pm 0.06 \mathrm{~g}$ worm/day(sheep manure) and $1.44 \pm 0.13 \mathrm{~g}$ worm/day(cattle manure), and produce ranged between $2.66 \pm 1.61$ worm $\mathrm{g} / \mathrm{Kg}$ substrate for sheep manure and41.33 \pm 3.27 worm g/ $\mathrm{Kg}$ substrate for cattle manure. This variability of results in feed substrates can be proved not only by the biochemical quality of the feed substrates but also by the capacity of substrates to provide earthworms with sufficient amount of easily metabolizable organic matter and nonassimilated carbohydrates (Edwards, 1988) and the palatability of different substrates (Tripathi and Bhardwaj 2004; Gajalakshmiet al., 2005). The higher growth rate $(1.44 \pm 0.13 \mathrm{~g}$ worm/day) and higher produce $(41.33 \pm 3.27$ worm $\mathrm{g} / \mathrm{kg}$ substrate) obtained in this study are similar to that obtained by Vodounnouet al. (2016)in their study entitled: effect of animal waste and vegetable compost on production and growth of earthworm (Eiseniafetida) during vermiculture where the higher growth rate and produce were respectively $1.35 \pm 0.11 \mathrm{~g}$ worm/day and $40.32 \pm 3.24$ worm $\mathrm{g} / \mathrm{kg}$ substrate. The higher produce and growth rate in the two studies agree that cattle manure is good for vermiculture. Others results like that of Bhatetal. (2015) proved that cattle manure mixed with the bagasse is also used in vermicompost.

Proximate composition of earthworm meal in different substrates:-

Earthworm is an animal species rich in protein. Earthworm meal is more rich in protein than fish meal and meat meal (Dedekeet al., 2010). For its quality it has been found to be an adequate replacement of fish meal in aquaculture and animal production. Protein content in earthworm meal is higher compared to the protein in fish meal, of: Salmogairdneri, Sarotherodonmelanotheron, Channastriatus, Snakehead murrel and Parachannaobscura (Kinsella et al.,1984, Baliuet al., 2007, Zuraini et al.,2006, Narhasan 2008, Ama-Abassi, 2013). Proximate 
composition of earthworm meal depends on the biochemical quality of the feed substrates. In this study, proteins, Nitrogen and ash varied with the different used feed substrates $(\mathrm{P}<0.05)$. The highest protein content in earthworm meal in this study was obtained with pig manure $51.38 \pm 0.05 \%$ and lowest with sheep manure $(42.45 \pm 0.08 \%)$. The higher protein content in earthworm meal induced by pig manure in this study can be ascribed to by the high organic matter and Carbon content of this manure compared to the other substrates. This result is different from that obtained by Shakorian (1991) where the protein in same species that our study (E.fetida) is 59\%.These two studies proved that earthworm feeding with the substrates, affect not only the production, but also the proximate composition of earthworm. But the earthworm species also affect the nutritional quality of earthworm. The crude protein of Lumbricusterrestrisis 32.60\% (Julendra, 2003), earthworm meal of Perionyxexcavatuscontained 57.2\% crude protein (Tram etal., 2005) . The same observation is reported with ash in earthworm meal. The ash rate varied with earthworm feeding substrates $(\mathrm{P}<0.05)$. It is ranged between $20.95 \pm 0.03 \%$ (poultry manure) and $13.51 \pm 0.05 \%$ (pig manure).

\section{Conclusion:-}

The nutritional analysis of earthworm meal in this study proves that earthworm can be used for fish meal and meat meal substitution in fish and animal diets. But the earthworm production and the biochemical quality of earthworm meal are affected by earthworm feeding substrates.

\section{Acknowledgements:-}

This study was supported by the Ministry of Higher Education and Scientific Research of Benin Republic which provided a PhD grant to D.S. Juste Vital VODOUNNOU. The authors of this paper would also like to thank the Beninese National Institute of Agricultural Research (INRAB) for their support.

\section{References:-}

1. Ama-Abasi,D., Ogar, A. (2013). Proximate Analysis of Snakehead Fish, Parachannaobscura, (Gunther 1861) of the Cross River, Nigeria. Journal of Fisheries and Aquatic Science 8 (1): 295-298.

2. AOAC,(2000). Official Methods of Analysis. $17^{\text {th }}$ Edition, Association of Official Analytical Chemistry, Alington, Virginia, USA.

3. Baliu, J.K., Ogu, J., Onwuemme, C. (2007). Condition factor, fat and protein content of five fish species in Lekki. Lagoon, Nigeria Life Science Journal4 : 54-57.

4. Bhat, S., Singh, J., Vig, A.P. (2015). Potential utilization of bagasse as feed material for earthworm Eiseniafetida and production of vermicompost. International Journal of Recycling Organic Waste in Agriculture.4:11 9p. DOI 10.1186/s40064-014-0780;

5. Bhorgin, L.A.J., Uma, K. (2013). Nutritional Evaluation of Earthworm Powder (Lampitomauritii). Journal of Applied Pharmaceutical Science. 3 (03): 082-084.

6. Changguo, X., Pingjiu, Z., Genxing, P., Duosheng, Q., Qiuhua, C. (2006).Changes in diversity, protein content, and amino acid composition of earthworms from a paddy soil under different long-term fertilizations in the Tai Lake Region, China.ActaEcologicaSinica, 26: 1667-1674. doi: 10.1016/S1872-2032(06)60030-9.

7. Dedeke, G.A.,Owa, S.O., Olurin, K.B. (2010). Amino acid profile of four earthworms species from Nigeria. Agriculture and Biology Journal of Nigeria. 1(2): 97- 102.

8. Dong, X.H., Guo, Y.X., Ji-Dan,Y.e., Song, W.D., Huang, X.H., Wang, H. (2010).Apparent digestibility of selected feed ingredients in diets for juvenile hybrid tilapia, Oreochromisniloticusx Oreochromisaureus.Aquaculture Research, 41: 1356-1364. doi: 10.1111/j.1365-2109.2009.02424.

9. DYNES, R.A.(2003).Eathworms technology information to enable the development of Eathworm production. Rural Industries Research and Development corporation RIRDC; 33pp .

10. Edwards, C.A. (1988). Breakdown of animal, vegetable and industrial organic wastes by earthworms.SPB Academic Publishing, Hague, pp:21-31.

11. Gajalakshmi,S., Ramasamy, E.V., Abbasi, S.A.(2005).Composting-vermicomposting of leaf litter ensuing from the trees of mango (Mangiferaindica). BioresourceTechnology 96 pp:1057-1061.

12. Julendra, H. (2003). Antibacterial activity test of earthworm meal as broiler feeds tuff to the bacteria growth of Salmonella pullorumwith invitro method. Research and Development in Technical Science and Knowledge.

13. Kinsella, J.E., Shimp, J.L., Mai, J., Weihrauch, J. (1984). Sterol, phospholipid, mineral content and proximate composition of filets of select freshwater fish species. Journal of Food and Biochemical.1 :131-140.

14. Lee, K.G. (1985). Earthworms: their ecology and relationships with soils and land use. Academic Press, Sydney, Australia. 
15. Manyuchi, M.M., Mudamburi, T., Phiri, A., Muredzi, P., Kanhukamwe, Q.C. (2014). Impact of vermicompost on peas cultivated soil. Global Journal ofEngineering Science and Researches. 1(1): 1-3.

16. Manyuchi, M.M., Phiri, A. (2013). Vermicomposting as a Solid Manure Management Strategy: A Review. International Journal ofScientificEngineeringandTechnology. 2 (12),1234-1242.

17. Narhasan, M. (2008). Nutritional composition of aquatic species in laotian rice field ecosystems : Possible impact of reduced biodiversity. Master's Thesis, international Fisheries Management, University of troms.

18. Paoletti, M.G., Buscardo, D.J., VanderJagt, A., Pastuszyn, L., Pizzoferrato, Y.S., Huang, L.T., Chuang, M., Millson, H., Cerda, F., Torres, G.R.H. (2011).Proceedingthe Royal Society of Biological Sciences.London P: 249-257.

19. Sabine, J. (1983).Earthworms as a source of food and drugs. In J.E. Satchell (ed) Earthworm ecology: from Darwin to vermiculture. Chapman and Hall, London, UK.

20. Safarkhanlo, L., Nagarestani, H., Amadi, H., Moaini, S. (2009). Journal of marine sciences Iran.Vol. 1:57 PP.30-26.

21. Saville, D.J. (1990). Multiple comparison procedures: the practical solution. American Statistic.44(2): 174-180.

22. Segovia, E. (1996). Analysisflsico-quimico de la harina de lombrizEiseniafoetida. Tesis de licenciatura, Ingenieria. Lima-Peru. UniversidadAgraria La Molina

23. Sogbesan, A.O., Ugwumba, A.A.A., Madu, C.T. (2007).Productivity potentials and nutritional values of semiarid zone earthworm (Hyperiodriluseuryaulos; Clausen, 1967) cultured in organic manures as fish meal supplement. Pakistan Journal of Biological Sciences, 10: 2992-2997.

24. Stafford, E.A., Tacon, A.G.J. (1984).Nutritive value of the earthworm, Dendrodrilussubrubicundus, grown on domestic sewage, in trout diet.Agricultural Wastes, 9(4): 249-266.

25. Sun, Z., Liu, X., Sun, L., Song, C. (1997).Earthworm as a potential protein resource.EcologyofFood Nutrition,36:221 236.doi:10.1080/03670244.1997.9991517.

26. Tacon, A.G.J., Stafford, E.A., Edwards, C.A. (1983).A preliminary investigation of the nutritive value of three terrestrial lumbricid worms for rainbow trout.Aquaculture, 35: 187-199. doi: 10.1016/00448486(83)90090-X.

27. Tram, N.D.Q., Ngoan, L.D., Ogle, B. (2005).Culturing earthworms on pig manure and the effect of replacing trash fish by earthworms on the growth performance of Cat fish (Clariasmacrocephalus $x$ Clariasgariepinus).theses $\mathrm{p} 2$.

28. Tripathi, G., Bhardwaj, P. (2004). Comparative studies on biomass production, life cycles and composting efficiency of Eiseniafetida (Savigny) and Lampitomauritii (Kinberg).Bioresource Technology 92 pp: 275-278. doi:10.1186/2251-7715-1-15

29. Tuan, N.N. (2010).Development of supplemental diets for carp in Vietnamese upland ponds based on locally available resources (PhD thesis).PhD in Agriculture Sciences, Stuttgart, University of Hohenheim.

30. Vodounnou, D.S.J.V.,Djissou, A.M.S.,Kpogue, D.N.S., Dakpogan,H., Mensah,G.A., Fiogbe, E.D. (2015). Review about the use of the Invertebrates in Pisciculture: Termites, Earthworms and Maggot. International Journal of Multidisciplinary and Current Research 3(3): 620-628.

31. Vodounnou, D.S.J.V., Kpogue, D.N.S.,Tossavi, C.E., Mensah, G.A., Fiogbe, E.D. (2016). Effect of animal waste and vegetable compost on production and growth of earthworm (Eiseniafetida) during vermicultureInternational Journal of Recycling Organic Waste in Agriculture 5:87-92 DOI 10.1007/s40093016-0119-5.

32. Zuraini, A., Somchit, M.N., Solihah, M.H., Goh, Y.M., Arifah, A.K.(2006). Fatty acid and amino acid composition of three local Malaysian Channa spp.Fish Food chem, 97:674-678. 